\title{
Effect of Processing on Quality Evaluation of Composite Flours
}

\author{
S. Kavitha ${ }^{1}$ and R. Parimalavalli ${ }^{2}$ \\ 'Department of Food"science and Nutrition, Periyar University, Salem, Tamil Nadu, India; \\ kavithabharathi31@gmailcom \\ ${ }^{2}$ Assistant Professor, Department of Food science and Nutrition, Periyar University, Salem, \\ Tamil Nadu, India; parimalavallidr@gmail.com
}

\begin{abstract}
The present study prepared aims to demonstrate the quality evaluation of roasted and germinated composite flours. Composite flour was prepared with wheat flour, maize flour, green gram flour and groundnut flour. Material balance method was followed to get the required proportions of flours. The samples of first batch were raw and considered as control flour. Second and third batch samples were roasted flour and germinated flour respectively. Roasting and germination were done by the standard methods. Proximate composition and functional properties were determined using the standard procedures.Protein content of germinated flour was significantly higher than other flours. Fat and carbohydrate were degraded significantly $(\mathrm{p} \leq 0.05)$ during processing. On germination, the water absorption index increased significantly at 5 per cent level indicating the ability of flour to absorb water and an increase in the amount of soluble materials, which can be easily digested. Germination increased water absorption capacity, foaming capacity and solubility whereas roasting significantly affects bulk density, oil absorption capacity, swelling capacity and emulsification capacity.The present study concludes that the composite flours have better qualities that could be harnessed by roasting and germination to meet nutritional requirements and recommended for incorporation in food preparations.
\end{abstract}

Keywords: Composite Flours, Germination, Proximate Composition, Roasting

\section{Introduction}

Composite flour technology is the process of mixing flours for making various food products [1]. Germination and roasting are the simple and easily adaptable technologies for reduction of bulkiness [2]. Germination, roasting and fermentation improves the nutritional quality of pulses and cereals-based foods [3]; and these methods also help to reduce cooking time and extend the shelf life of food [4]. Germination/sprouting/malting is a biochemical process which involves transition of a seed from dormant state to vital active state. It is a simple technique that improves the nutritive value of foods. Moreover roasting of grains denatures proteins and improves their digestibility [5].Among cereals, most inhabitants use wheat as an ample food due to the scrupulous properties of Proteins in flour [6]. Maize was traditionally grown as staple food, primarily for household consumption [7]. Amongst legumes, mung bean is a widely consumed pulse and is high in protein (25\%), dietary fibre, vitamins and minerals [8]. Groundnut is widely consumed legume and it is rich in oil (48-49\%) and protein (about 26\%) [9]. Processing of a raw food material can modify proteins and other components which can change the functionality and nutritional quality of the final product. The term "functionality" in the context of food ingredients, is defined as "any property, aside from nutritional attributes, that influences an ingredient's usefulness in food" [10]. The ultimate success of using protein rich flours depends upon their functional attributes after processing and

*Author for correspondence 
how they interact with other ingredients in the final prouct. Application of flour from different sources in food systems depends greatly on physiochemical and functional properties of such food materials. Physicochemical changes in flour proteins are known to affect functional properties such as water and fat absorption capacities, protein solubility and foaming characteristics [11]. This study was aimed to formulate composite flour with cereals and legumes applying roasting and germination and to evaluate the proximate composition and functional properties of the composite flours.

\section{Materials and Methods}

\subsection{Processing of Raw Materials}

The materials such as wheat, maize, mung bean and groundnut were cleaned, shade dried and divided into three batches. The first batch of material was raw and considered as control. Second and third batch samples were roasted and germinated respectively by standard procedures.

\subsection{Formulation and Preparation of Mixture}

Formulation is based on carbohydrate, protein, and fat content of the blends. Algebraic equation is able to provide formulation that best fit the nutrient requirements for infant's food. From this design we obtained 4 systems of equation:

Using protein (15\%), carbohydrate (above $55 \%)$ and fat (7\%) as the constraints (targets), the following equations were obtained:

$$
\mathrm{A}+\mathrm{B}+\mathrm{C}+\mathrm{D}=100
$$

Where $\mathrm{A}=$ Wheat (Triticum aestivum) $+\mathrm{B}=$ Maize (Zea mays $)+C=$ Mungbean flour (Vigna Radiata $L)+D=$ Groundnut (Arachis hypogea).

$$
\begin{aligned}
& 0.118 \mathrm{~A}+0.111 \mathrm{~B}+0.24 \mathrm{C}+0.253 \mathrm{D}=15 \\
& 0.712 \mathrm{~A}+0.662 \mathrm{~B}+0.567 \mathrm{C}+0.261 \mathrm{D}=61.8 \\
& 0.015 \mathrm{~A}+0.036 \mathrm{~B}+0.013 \mathrm{C}+0.401 \mathrm{D}=7
\end{aligned}
$$

Of these:

The line (1) was the representation of total mix

The line (2) was the protein equation

The line (3) was the carbohydrate equation

The last line (4) was the fat equation

There were several methods by which this resolution may be done. Algebraic calculations permit to find the amounts of the flours needed. The amount of each flour to be used was obtained by solving these four systems of equation. $\begin{array}{lllc}\text { Solving the above four equations } & \text { by } \\ \text { using } & \text { MatLab software } & \text { results } & \text { in: } \\ & A=39 \%, B=34 \%, C=14 \% \text { and } D=13 \%\end{array}$

\subsection{Determination of Proximate Compositio}

Moisture, protein, ash, crude fiber and fat were estimated using the AOAC method [12]. Carbohydrate was calculated by difference as the sum of the moisture, fat, protein and ash contents were subtracted from 100 as given in AOAC [12]. Food energy value of the samples was determined by the method given by Osborne and Voogt [13]. The energy value $(\mathrm{kcal} / 100 \mathrm{~g})$ is calculated based on the protein, fat and carbohydrate content.

\subsection{Determination of Functional Properties}

Bulk Density (BD), Water Absorption Capacity (WAC) and Oil Absorption Capacity (OAC), Emulsion Capacity (EC), Swelling Capacity (SC) and Foaming Capacity (FC) were determined using standard methods.

\section{Results and Discussion}

\subsection{Proximate Composition of the Composite Flours}

From Table 1 moisture content of GCF was found to be the highest $(8.10 \pm 1.62 \%)$ followed by CCF $(7.88 \pm 1.25 \%)$ and RCF $(6.40 \pm 1.18 \%)$. The different processing methods employed in this study increased the moisture content in order: Roasting $<$ Control $<$ germination.

Table 1. Proximate composition of the composite flours

\begin{tabular}{|l|l|l|l|}
\hline \multicolumn{1}{|c|}{ Nutrients } & \multicolumn{1}{|c|}{ CCF } & \multicolumn{1}{c|}{ RCF } & \multicolumn{1}{c|}{ GCF } \\
\hline & & & \\
Moisture (\%) & $7.88 \pm 1.25^{\mathrm{a}}$ & $6.40 \pm 1.18^{\mathrm{b}}$ & $8.10 \pm 1.62^{\mathrm{c}}$ \\
Ash (\%) & $1.82 \pm 0.10^{\mathrm{NS}}$ & $1.85 \pm 0.09^{\mathrm{NS}}$ & $1.88 \pm 0.17^{\mathrm{NS}}$ \\
Protein (\%) & $14.12 \pm 1.18^{\mathrm{a}}$ & $16.03 \pm 1.32^{\mathrm{b}}$ & $21.24 \pm 2.60^{\mathrm{c}}$ \\
Fat (\%) & $6.92 \pm 1.02^{\mathrm{a}}$ & $5.37 \pm 0.68^{\mathrm{b}}$ & $5.23 \pm 0.89^{\mathrm{c}}$ \\
CrudeFibre (\%) & $3.30 \pm 0.48^{\mathrm{a}}$ & $2.53 \pm 0.36^{\mathrm{b}}$ & $2.42 \pm 0.47^{\mathrm{c}}$ \\
Carbohydrates(\%) & $59.23 \pm 3.56^{\mathrm{a}}$ & $57.45 \pm 4.58^{\mathrm{b}}$ & $54.02 \pm 4.67^{\mathrm{c}}$ \\
Energy (Kcal) & $350.69 \pm 26.35^{\mathrm{a}}$ & $348.26 \pm 35.12^{\mathrm{b}}$ & $346.15 \pm 27.25^{\mathrm{c}}$ \\
\hline
\end{tabular}

Means with superscripts are significantly different at 5\% level. CCF - Control Composite Flour, RCF - Roasted Composite Flour, GCF - Germinated Composite Flour CCF had significantly higher crude fibre values as compared to GCF and RCF. Protein content of composite flours varied between $14.12 \pm 1.18 \%$ in CCF and $21.24 \pm$ $2.60 \%$ in GCF. However, the protein content of both germinated 
and roasted composite flours were significantly higher than CCF $(\mathrm{p}<0.05)$. The increased protein content could be due to proteases in the germinating seeds [14] Fat content of RCF and GCF was significantly $(\mathrm{p}<0.05)$ less than CCF. Decrease in the. fat content of the germinated blend might be due to the increased activities of lipolytic enzymes. These enzymes hydrolyze fats to simpler products which serve as a source of energy for the developing embryo.

The germinated sample had significantly lower crude fibre values as compared to non-germinated sample. It might be because the activity of enzyme alphagalactosidase increases which reduces levels of dietary fibre during germination. The decrease in the polysaccharide and mucilage content may be due to their utilization by the growing sprouts.

Carbohydrate content was decreased significantly $(\mathrm{p}<0.05)$ in GCF than CCF and RCF. $\beta$-amylase activity that hydrolyzes the starch into simple carbohydrate was increased.

Moreover energy content of RCF and GCF was significantly $(\mathrm{p}<0.05)$ lower than CCF. Germination is a life process for the sprouting plant, the energy reserves were being used for the metabolic activities of the young shoot. Thus, germination has a negative impact on energy content [15].

\subsection{Functional Properties of Composite Blends}

Table 2. Functional properties of composite blends

\begin{tabular}{|l|l|l|l|}
\hline \multicolumn{1}{|c|}{$\begin{array}{c}\text { Functional } \\
\text { Properties }\end{array}$} & \multicolumn{1}{|c|}{$\begin{array}{c}\text { Control } \\
\text { Blend }\end{array}$} & \multicolumn{1}{|c|}{$\begin{array}{c}\text { Roasted } \\
\text { Blend }\end{array}$} & \multicolumn{1}{|c|}{$\begin{array}{c}\text { Germinated } \\
\text { Blend }\end{array}$} \\
\hline Bulk density (g/ml) & $0.85 \pm 0.03^{\mathrm{a}}$ & $0.81 \pm 0.02^{\mathrm{b}}$ & $0.79 \pm 0.01^{\mathrm{c}}$ \\
WAC (g/g) & $1.43 \pm 0.04^{\mathrm{a}}$ & $1.19 \pm 0.03^{\mathrm{b}}$ & $1.62 \pm 0.06^{\mathrm{c}}$ \\
OAC (g/g) & $0.68 \pm 0.10^{\mathrm{a}}$ & $0.62 \pm 0.21^{\mathrm{b}}$ & $0.58 \pm 0.11^{\mathrm{c}}$ \\
Swelling capacity (ml) & $16.14 \pm 0.04^{\mathrm{a}}$ & $14.10 \pm 0.03^{\mathrm{b}}$ & $13.24 \pm 0.06^{\mathrm{c}}$ \\
Solubility (ml) & $2.30 \pm 0.65^{\mathrm{a}}$ & $3.45 \pm 0.21^{\mathrm{b}}$ & $4.00 \pm 0.57^{\mathrm{c}}$ \\
Foaming capacity (\%) & $16.40 \pm 0.01^{\mathrm{a}}$ & $13.46 \pm 0.06^{\mathrm{c}}$ & $17.65 \pm 0.03^{\mathrm{b}}$ \\
Emulsification capacity (\%) & $0.68 \pm 0.01^{\mathrm{a}}$ & $0.48 \pm 0.02^{\mathrm{b}}$ & $0.56 \pm 0.02^{\mathrm{c}}$ \\
\hline
\end{tabular}

Values with superscripts are significantly different at $(\mathrm{p}<0.05)$.

Processing significantly $(\mathrm{p}<0.05)$ affected bulk density. Germinated blend has the lowest bulk density. Low bulk density of the blend might be attributed to hydrolysis of its carbohydrate and fat and their subsequent utilization for growth leading to reduction in its weight [16]. King and Puwastien [17] made similar observation.

WAC values for the blends ranged from 1.43 (control) to $1.62 \mathrm{~g} / \mathrm{g}$ (processed). Significant difference $(\mathrm{P}<0.05)$ was noted in the WAC of the samples.
The germinated sample had higher WAC than the control and roasted samples. On germination, the WAI increased significantly $(\mathrm{p}<0.05)$ indicating the ability of flour to absorb water. Thus, higher WAC of germinated samples may be due to dissociation of the protein subunits during the germination.

Significant differences were observed in OAC of the samples. OAC of the samples ranged from 0.58 to 0.68 $\mathrm{g} / \mathrm{g}$. There was a significant $(\mathrm{P}<0.05)$ decrease in $\mathrm{OAC}$ of processed samples. This could be attributed to configurational changes in constituents of samples on processing. The highest value of OAC was 0.68 for control sample followed by the roasted sample (0.62) while the least value (0.58) was observed for germinated sample. Oil retention is due to physical entrapment of the lipid by the protein [18]. There was a significant difference $(\mathrm{P}<0.05)$ in the swelling capacity of the samples. The SC of the blends ranged from 13.24 to $16.14 \mathrm{ml}$. The control sample had the maximum SC of 16.14, while the germinated blend had the least value.

Foaming capacity decreased from a value of $17.65 \%$ in the germinated blend to a value of $13.46 \%$ in the roasted blend. Germinated samples had the highest foam capacity value (17.65\%) among the blends while the roasted blend has the least (13.46\%) value. This low value for the roasted flour is due to higher degree of protein denaturation.

Heating decreased emulsion capacity of blend samples. Control and germinated blends had emulsion capacities of 0.68 and $0.56 \%$ respectively. The lower value $(0.48 \%)$ for the roasted sample is due to a higher degree of protein denaturation caused by dry heat, since the emulsion capacity is based on nature of protein molecules and its surface properties [19].

\section{Conclusion}

The study concluded that roasting and germination affect the qualitative and quantitative characters proximate of composite flours. Germination increased moisture and protein content in composite flours. Roasting and germination significantly affect ash, fat, fibre, carbohydrate and energy content. Germination increased water absorption capacity, foaming capacity and solubility whereas roasting significantly affects bulk density, oil absorption capacity, swelling capacity and emulsification capacity. From this study, it is noted that composite flours have good nutrient content, which could be improved to suit the various needs. 


\section{References}

1. Dendy D. A.V., and Dobraszczyk B. J., Composite and alternative flours, cereals and cereal products: chemistry and technology, Chapter 11, Aspen publication, USA: p. 263-273, 2001.

2. Gernah D. I., Ariahu C. C., and Ingbian E. K. "Effects of malting and lactic fermentation on some chemical and functional properties of maize (Zea mays)". Am. J. Food Tech., vol. 6(5), p. 404-412, 2011.

3. Ayet G., Burbano C., Cuadrado C., Pedrosa M. M., Robredo L. M., and Muzquiz M. "Effect of germination, under different environmental conditions, on saponins, phytic acid and tannins in lentils (Lens culinaris)", J. Sci. Food Agr., vol. 74, p. 273-279, 1997.

4. Badifu G. I. O., and Ebegonye G. M., "Effect of germination on chemical, physical and functional properties of defatted flour of melon (Cirullus vulgaris) kernel", J. Food Sci., vol. 36(1), p. 63-66, 1999.

5. Boye J., Fatemeh, Z., and Pletch A., "Pulse proteins: Processing, characterization, functional properties and applications in food and feed", Food Res. Int., vol. 43, p. 414-431, 2010.

6. Traore T., Mouquet C., Icard-Verniere C., Traore A. S., and Trecie S., "Changes in nutrient composition phytate and cyanide contents and amylase activity during cereal malting in small production units in Ouagadougou (Burkina Faso)". Food Chem., vol. 88, p. 105-114, 2004.

7. Adetuyi F. O., Badejo O. F., Ikujenlola A. V., and Omosuli S. V., "Storage influence on the functional properties of malted and unmalted maize (Zea mays L ssp. mays) and soybean (Glycine max L Merrill) flour blends", Afr. J. Food Sci., vol. 3(2), p. 056-060, 2009.

8. Paul T., Rubel-Mazumdar N.H.M, Sayed M. A., and Akhataruzamman M., "Proximate composition, mineral content and determination of protease activity from green gram", Bangladesh Research Publication Journal, vol. 5(3), p. 207-213, 2011.
9. Adeyeye E. I., and Aye P. A., "The effects of sample preparation on the proximate composition and the functional properties of the African yam bean flours", Note 1 La Rivista Italiana Della Sostanze Grasse, LXXV- Maggio, 253-261, 1998.

10. Fennema O. R. Food chemistry. Marcel Dekker, Inc., New York, p. 245-370, 1996.

11. Kerr W. L., Ward C. D. W., Mcwatters K. H., and Resurrecsion A. V. A., "Milling and particle size of cowpea flour and snack chip quality". Food Res. Int., vol. 34, p. 39$45,2000$.

12. AOAC, "Official methods of analysis, Association of Official Analytical Chemistry", 15th Edition, 1990.

13. Osborne D. R., and Voogt P., The Analysis of nutrients in foods, 6th Edn., London Academic Press, p. 239-245, 1978.

14. Rodriguez C., Frias J., Vidal-Valverde C. and Hernandez A., "Correlations between some nitrogen fractions, lysine, histidine, tyrosine, and ornithine contents during the germination of peas, beans, and lentils". Food Chem., vol. 108(1), p. 245-252, 2008.

15. Alex A. A., Kelly A. R., Odean M. L., Fulcher R. G., and Susan D. A., "Influence of added bean flour (Phaseolus vulgaris L.) on some physical and nutritional properties of wheat flour tortillas", Food Chem., vol. 109, p. 33-41, 2008.

16. Oluwamukomi M. O., Eleyemi A. F., Enujiugha V. N., and Atofarati S. O., Nutritional, physico-chemical and sensory evaluation of sorghum and cowpea based weaning formulations. Niger Food J., vol. 21, p. 11-17, 2003.

17. King R. D., and Puwastien P., "Effect of blanching and soaking on winged bean (Psophocarpus teragonolobus)". J. Sci. Food Agric., vol. 35(4), p. 441-446, 2006.

18. Padmashree T. S., Vijayalakshmi L., and Pultaraj S., "Effect of traditional processing on the functional properties of cowpea (Vigna catjany) flour". J. Food Sci. Tech., vol. 24, p. 221-224, 1987.

19. Shamasunder B. A., and Prakash V., "Effects of blanching on frozen storage of prawns (Physicochemand functional properties)". J. Agric. Food Chem., vol. 42, p. 126-128, 1994. 